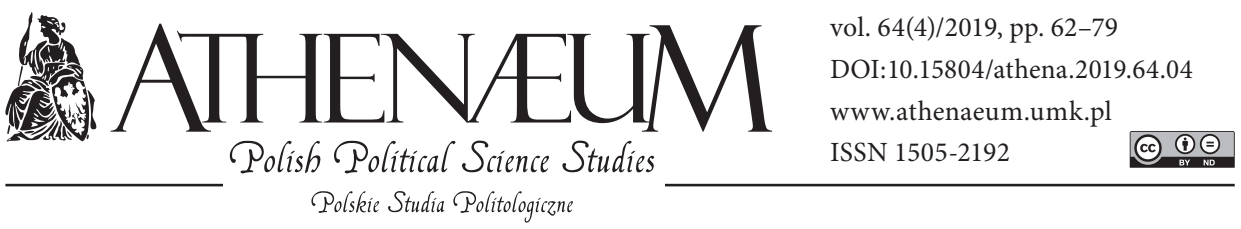

\title{
GEOPOLITICAL IMAGINATION OF THE POLITICAL ELITES OF THE THIRD POLISH REPUBLIC: AN OUTLINE OF THE PROBLEM
}

\author{
WYOBRAŹNIA GEOPOLITYCZNA ELIT POLITYCZNYCH III RP: \\ ZARYS PROBLEMU
}

Jarosław Macała* $\odot$

\begin{abstract}
The article deals with the issue of the development of geopolitical imagination of Polish political elites following 1989. The source database of the text are the most important official documents regarding the foreign policy of the Third Polish Republic: the policy statements of subsequent prime ministers and the so-called small policy statements of the ministers of foreign affairs. Discourse analysis and system analysis were used to analyse them, treating them as a social construct. Geopolitical imagination placed Poland in Europe, in the dangerous zone between Germany and Russia and on the border of the two civilizations. The escape from this "fatalism of geography" was the main goal of the elites of the Third Polish Republic. Hence the orientation towards the West, to ensure the exit from peripherality, security and development. To justify such a remodelling of their representations, the elites put forward an idealized image
\end{abstract}

Artykuł dotyczy kształtowania się wyobraźni geopolitycznej polskich elit politycznych po 1989 roku. Bazą źródłową tekstu są najważniejsze oficjalne dokumenty dotyczące polityki zagranicznej III RP: exposé kolejnych premierów oraz tzw. małe exposé ministrów spraw zagranicznych. Dla ich analizy zastosowano analizę dyskursu oraz analizę systemową, traktując treść dokumentów jako społeczny konstrukt. Wyobraźnia geopolityczna lokowała Polskę w Europie, w niebezpiecznej strefie między Niemcami a Rosją oraz na granicy dwóch cywilizacji. Wyjście z tego „fatalizmu geografii” było zasadniczym celem elit III RP. Stąd orientacja na Zachód, żeby zapewnić sobie wyjście z peryferyjności, bezpieczeństwo i rozwój. Dla uzasadnienia takiej przebudowy swoich imaginacji elity posługiwały się idealizowanym obrazem Zachodu. Ułatwiało to akceptację dokonanego wyboru geopolitycznego przez społeczeństwo oraz związane z nim

* University of Zielona Góra, Faculty of Humanities. 
of the West. It facilitated the acceptance of the geopolitical choice made by the society and the associated severe limitation of Poland's geopolitical and economic autonomy. The vehicles on the way to the West were bandwagoning towards the USA and Germany, which justified clientelism towards them. In various combinations, the representations about Poland's key role in the post-communist region re-emerged following 1989 to strengthen its position in relation to the West and the East. As for the eastern direction, Poland's goal was to move the imaginary borders of the West towards our eastern neighbours, mainly Belarus and Ukraine. This must have led to the negative reaction from Russia, which considered this area its sphere of influence. Russia was imagined by us to be an alien and enemy, and the change of this state of affairs would be a consequence of the Westernisation of Russia so desired by the Polish elites. It seems that in the years 1989-2015, one could speak of a certain interpretative community, which the LaJ (Law and Justice/Prawo i Sprawiedliwość) governments broke down following 2015. The LaJ foreign policy has become a hostage of those undermining the liberal democracy of internal political system changes. Their criticism in the EU states isolates and pushes towards servility to Washington. In turn, the Three Seas Initiative is too divided and weak to leverage Poland's position. It seems that re-approaching the EU's core may give us some freedom and better protection in external policy.

Keywords: geopolitics; geopolitical imagination; critical geopolitics; Polish foreign policy; Third Polish Republic silne ograniczenie autonomii geopolitycznej i ekonomicznej Polski. Wehikułami na drodze na Zachód był bandwagoning wobec USA i Niemiec, co uzasadniało na ogół klientelizm wobec nich. W różnych kombinacjach powracały po 1989 roku wyobrażenia o kluczowej roli Polski w regionie postkomunistycznym, żeby wzmocnić jej pozycję w stosunku do Zachodu i Wschodu. W przypadku kierunku wschodniego celem Polski było przesunięcie wyobrażonych granic Zachodu na naszych sąsiadów, głównie na Białoruś i Ukrainę. Musiało to spowodować negatywną reakcję Rosji, uważającej ten obszar za swoją strefę wpływów. Rosja była w naszych wyobrażeniach traktowana jako obcy i wróg, a zmiana tego stanu rzeczy byłaby konsekwencja pożądanej przez polskie elity okcydentalizacji Rosji. Wydaje się, że w latach 1989-2015 można mówić o pewnej wspólnocie interpretacyjnej, której załamanie przynoszą rządy PiS po 2015 roku. W ich wyobrażeniach odsuwamy się od zachodniej Europy, zdając się na uległość wobec Amerykanów oraz na współpracę regionalną pod polskim przywództwem. Polityka zagraniczna PiS stała się zakładnikiem podważających liberalną demokrację wewnętrznych zmian ustrojowych. Ich krytyka w państwach UE powoduje izolację i zdaje na serwilizm wobec Waszyngtonu. $\mathrm{Z}$ kolei Trójmorze jest zbyt podzielone i słabe, żeby wydźwignąć pozycję Polski. Wydaje się, że ponowne zbliżenie do rdzenia UE może nam dać pewną swobodę i lepszą asekurację w polityce zewnętrznej.

Słowa kluczowe: geopolityka; wyobrażenia geopolityczne; geopolityka krytyczna; polska polityka zagraniczna; Trzecia Rzeczpospolita Polska

\section{INTRODUCTION}

The literature on critical geopolitics and geographical or geopolitical imaginations/representations is quite extensive in the West. It illustrates a complicated, interdisciplinary field of research, in which we are dealing with an ambiguous 
understanding of key concepts, generally formulated in English. In addition, creating a coherent methodology in the context of interdisciplinary research poses significant problems. In Polish literature, studies in critical geopolitics are not very advanced, which also applies to the title problem. On the other hand, the problem matter of the concept of Poland's foreign policy following 1989 and its implementation has been the subject of numerous studies and publications. Still, it is worth turning to studies on geopolitical imaginations in the Third Polish Republic, which had to re-determine sovereignly the place of Poland in Europe and adjust external relations (Zięba, 2012).

The source basis of the article are the most important documents regarding the assumptions of foreign policy of the Third Polish Republic. Those are the policy statements of the subsequent prime ministers whose delivery in the Sejm constitutes the constitutional duty of a candidate for the head of government. In general, such a program statement has a deliberate structure and hierarchy of content dominated by internal problems. However, there were also more or less extensive remarks about Poland's foreign policy. The second part of the sources is the information presented each year by the Minister of Foreign Affairs at the Sejm's forum, i.e., information about Poland's foreign policy (the so-called small policy statement). It is the most important document on the foreign policy of the Polish state in a given year required by law, containing a programmed structure, hierarchy of meanings and an expanded survey of the world.

This study only signals some problems. The research basis method shall be, on the one hand, the analysis of the dominant discourse of the political elites, focused on its study as an instrument of power and politics, and a systemic analysis, treating the geopolitical imagination as an internally complex and related system of social constructs, on the other. The basic research questions are summarized as follows: What framed the shape of the Polish geopolitical imagination following 1989? What did it consist of? How did it affect Poland's foreign policy? As for the main hypothesis, my attempt is to prove its continuity in the Third Polish Republic, which breaks down as a system only during the LaJ government, i.e., following 2015. 


\section{GEOGRAPHICAL IMAGINATION}

In contemporary science, the increasingly more important role is played by the post-positivism approach, relatively unknown in Poland. It should be noted that its rather characteristic features are: opposition to the positivist vision of the world and science, which also means that social sciences and humanities are not free from values nor neutral. Social reality is not something objective, but it is subject to constant social construction. It also means that social relations consist more of thoughts and ideas rather than of material elements. Then they become an expression of a vision of the world, a specific ideology and political interests, they offer only fragmentary and partial cognition, not a comprehensive and normative one. Human understanding of the world results from the fact that humans developed it, created it in their minds. Hence, the study of language, signs, symbols, beliefs, interpretations, discourses, norms and identities seems so important to understand social relations (Gasztołd, 2018).

For these considerations, the starting point is the change in the meaning of geography, which took place in the second half of the $20^{\text {th }}$ century. It is worth referring to the term of "imaginative geography", coined in the $1970^{\text {s by an out- }}$ standing literary scholar Edward W. Said. He argued that imaginative geography is an arbitrary, discursive practice of designating particular spaces that are "ours" and spaces of "aliens" in our minds. As a consequence, "aliens" are accordingly labelled as "them", and their territory and mentality as "different" and "alien" from "ours" (Said, 2005).

On the other hand, one must refer to the "geographical imagination" consisting of pluralistic geographical representations. The term itself was created by the left-wing geographer David Harvey in the 1970s. For him, geographical imagination was part of human consciousness and identity, enabling each person to recognize the role of space and place in their own biography, to tell what they see around them. For space, of course, is one of the basic physical dimensions of human life, and that is why it becomes deeply permeated by human relations and their products. Hence, it has to be studied in social, cultural and historical as well as national contexts. It is so, as every community, in the course of history, develops its concepts of space and time and adapts to its own goals and values (Harvey, 2005).

Derek Gregory in 1994, in a controversial way, identified imaginative geography with geographical imagination as spatially conditioned by cultural and historical knowledge characterizing social groups. Therefore, knowledge is 
produced in which space is both a means and a result of social action and social relations. Showing complicated relations of power and identity in the "us-them" relations, the development of myths, stereotypes, etc. (Gregory, 1994).

\section{GEOPOLITICAL IMAGINATION AND CRITICAL GEOPOLITICS}

The notion of critical geopolitics is difficult to define and perceive geographically (Flint, 2008). However, the relation between geographic imagination and the notion of geopolitical imagination coined in this field is unclear. It concerns socially constructed relations between imaginary geography and foreign policy and state security. It expresses in the continuously produced and modified discursive practices a vision of the place of a specific nation and state in world politics and the related relations of power and conflicts in a certain geographical area. Geopolitical imagination in the long run and in a complicated way affects the history and culture of a given society or nation (Potulski, 2010).

The close relationship with practice seems to be important. It provides public justification for foreign policy, creating dynamic structures serving the national interests of individual states. It must, therefore, consider the representation of the territorial limitations of each state and geographic imagination, which are based on national identity and emotional ties with a given territory. Their basis, referring to the famous concept by Carl Schmitt, is the division into allies and enemies, the division into "our" and "their" space (Güney \& Gökcan, 2010).

\section{THE MYTH OF THE WEST}

The East-West civilization and geopolitical polarization has become the basic criterion for organizing and assessing the Polish geopolitical imagination for the last 200 years. Its essence was the diversification in the Polish discourse into "our", "better" West, and "alien", "worse" East, and nowadays between western democracy and eastern autocracy. The imagined place of Poland in Europe was determined by the orientational metaphors in the discourse of political elites, establishing the foundations of self-identification and the main geopolitical axis. Thus, we found ourselves between the two powerful neighbours - Russia and Germany, in the region which "is the point of intersection and the collision of oriental and occidental influences, the line designated on the map of Europe by 
unsuccessful attempts at domination" (Škrabec, 2013). Since geography cannot be changed, it is worth changing geopolitics, which framed the direction of building a modern, state-centric geopolitical imagination (Potulski, 2010), to make a departure from the mythologized and enslaving "fatalism of geography" imposed since the period of partitions. To ensure independence and the necessary modernization of the state (Kuźniar, 2008; Zięba, 2012).

A phenomenon closely related to the creation of geopolitical imagination is often a tendency to put other countries and their visions of international relations as a model worth following. In that way, the geopolitical imagination of the Polish elite clearly placed the West at the centre of the world, as an idealized civilization leader, a symbol of freedom, democracy, wealth, stability and security. Also as the winner of the Cold War, dictating the conditions of the new world order and therefore interested in extending the zone of its values and influences to the post-communist countries. The Westernisation desired by the Polish elites meant not only the imaginary shifting of Poland from east to west, but also a clear change in the division into her own and aliens compared to the period of the PPR (Polish People's Republic). Former official enemies became allies, and the forced hegemon from the communist period was treated as an alien or even an outright enemy.

First, the justification of the Westward course was associated with shared identity. For, with baptism, Poland "became a joint-heir in the tradition of antiquity and Christian identity" and was introduced "into the political bloodstream of the Latin world" (Sikorski, 2008). However, the heart of this "bloodstream" was Western Europe for centuries, developing our inferiority complex especially for the last two centuries. From there, there flowed to us, to the peripheries, the cultural, religious, economic, political patterns, etc., which we critically adapted to our realities.

Secondly, with the necessary systemic and socio-economic change of Poland. After all, we aspired to an inclusive community of the prosperous and stable democratic world, which contrasted with the enslavement and backwardness of the People's Republic. Since Poland for at least half a century did not enjoy a democratic experience or capitalist economy, there again was the necessity to imitate Western values and models, but this time in a generally uncritical manner (Kuisz, 2016).

Westernisation was presented in the discourse as a unanimous will of the elites and society. This, combined with widespread sympathy, but also the West's complex in our society, evoked a positive emotional response, united Poles, mobi- 
lized social energy, legitimized the choice of the elites and facilitated acceptance of political and economic alliances that were far from partner-like for our state (Skubiszewski, 1993; Miller, 2001).

\section{THE PROTECTORS - THE USA AND GERMANY}

The way to the centre, to the West, was to be facilitated by the acquisition of powerful patrons as part of the bandwagoning strategy. Prime Minister Donald Tusk commented on the idea in 2007: "We must and we want to treat our allies seriously, we must and we want to show them solidarity. We would expect the same from them if Poland found herself in need" (Tusk, 2007). There was a dissonance between the words that we "must and want" and "we expect" from them, which illustrated the patron-client relationship.

The key in the discourse concerning the guarantee of Poland's security and independence was the establishment in the $1990^{\mathrm{s}}$ of allied relations with the world and western hegemony - the USA, a socially idealized symbol of freedom, power, security and prosperity, attractive to many Poles (Kuźniar, 2008). The strongly pro-American attitude of the elites and society facilitated the acceptance of subordination to Washington and its vision of the world, as it was supposed to "contribute to the benefits resulting from the influence of this power on the international order" (Grosse, 2016). It was primarily about the two important geopolitical dimensions. On the one hand, the USA was to pave the way to NATO for Poland and other post-communist countries to obtain effective security guarantees. It meant accepting the American hegemonic vision of the international order, its values and principles, and the threats that lurked on it. On the other hand, the goal was also to strengthen the geopolitical position of Poland for her to become - with the support of Washington - a leader of Central and Eastern Europe, as "close relations with the United States are among the biggest advantages of our foreign policy" (Bartoszewski, 2001).

The vassalisation of Poland in the relations with the USA reached its apogee during the presidency of George Bush junior (2001-2009), deemed to be attentive to "Polish affairs", which justified the fulfilment of all Washington's wishes (Rotfeld, 2005). Its symbol was the uncritically accepted American Manichean vision of the world in the form of the war on terrorism (Cimoszewicz, 2003; Zięba, 2012). A narrative was constructed for the public at that time, that in this way, high credibility of Poland was established as an important ally (Rotfeld, 2005). 
However, the proof of the actual US recognition for the prestige of Poland was our barely fruitful participation in the American interest in the wars in Afghanistan and Iraq. In them, the global hegemon exploited its satellite and shifted some of the costs of its own politics onto it, which translated into less enthusiastic pro-American social moods and problems of Poland in relations with the most powerful states of the European Union. The elites had to react to this, distancing themselves from some of the actions of the American ally.

Following this trait in 2008, the Civic Platform (CP) attempted to visually limit the vassalisation, as the actual room for geopolitical manoeuvre was small. It created a new narrative for the society, namely that its policy is more focused on Western Europe, and in relation to the USA will be less compliant and firmer, criticizing the servility of the Democratic Left Alliance (DLA) and the Law and Justice (LaJ) governments (Sikorski, 2009). It was symbolic when Donald Tusk's government withdrew the Polish troops from Iraq and voiced its scepticism about the anti-missile shield.

On the other hand, the return of LaJ to power in 2015 made another visual attempt to get closer to Washington in the conditions of a growing threat from Russia and much worse transatlantic relations and isolation of Poland in the $\mathrm{EU}$ as a result of criticism of the systemic changes. In the vision of this party, the USA "is today and shall remain in the foreseeable future the main guarantor of world peace" (Szydło, 2015). Hence the belief that Americans, directly and through NATO, shall safeguard Poland's security and strengthen her position in Europe and the region in exchange for the full submission of Warsaw. However, in practice, in the name of internal policy goals, LaJ governments have strongly limited Poland's room for manoeuvre in foreign policy, moving away from core EU countries and relying on US favour which, involved in global politics, has different priorities than Warsaw. LaJ leaders poorly understand that servility towards Americans does not strengthen our position in relations with them.

Since "the shortest route to Europe" led through Germany, striking an alliance with Berlin was indispensable on the way to the western centre, mainly to the EU (Bielecki, 1991; Borodziej, 2006). However, it required a thorough change of some Polish geopolitical representations. For, since the period of the Partitions, Prussia/Germany acted as an enemy, which was even more reinforced by the historical memory of World War II and its consequences (Skubiszewski, 1991).

The elites, in order to create a new vision of Germany in the first decade of transformation, exploited the increasingly stronger social attitudes in Poland to appreciate the normality and peacefulness of the western neighbour and its firm 
anchoring in the world of the democratic West. It was accompanied by gestures of admiration for the wealth and power of the FRG, as a desirable model of socio-political and economic changes (Czapliński, 2017). All of the above factors quite successfully demythologized the German threat, motivating the society to move away from the "curse" of mutual history to "reconciliation", facilitated the acceptance of clientelism towards Germany under the slogan of "geopolitical and economic community of interests" (Bartoszewski, 1995).

However, with our country's entry into the European Union in 2004, the position of Poland increased, and German aid was less needed in the narrative of our elites. There were two fundamental views on Polish-German relations at that time. One line involved the attempts made in 2004-2007 to relax the dominance of Berlin expressed by the DLA government temporally: "The time has come to define the Polish-German common interests anew" (Cimoszewicz, 2004). In another variant on the part of LaJ (in the years 2005-2007) the categorical: "we must work together to develop new, solid foundations for our strategic relationships" (Fotyga, 2007). It was about constructing the image of greater subjectivity of Poland, which the LaJ government has also been trying unsuccessfully to implement following 2015. At the same time, it triggers anti-German resentments, and the result is the cool-down in the mutual relations.

The government of Donald Tusk, in turn, in 2007-2014 recognized the asymmetric alliance with Berlin as the basis for building Poland's position in the EU and the condition for faster economic development. In his vision, the difficult history should not be forgotten, yet one was to look optimistically to the future. For the most powerful in the EU, Germany reciprocated with striving for a "partnership dialogue of a strategic nature, following the example of German-French relations" (Sikorski, 2008). The then head of the Ministry of Foreign Affairs therefore assumed the community rhetoric: "With Germany we share a common, strategic vision of the future of the Union and similar recipes for getting out of the crisis" (Sikorski, 2013).

After 2015, we started moving away from Germany. On the one hand, this is a consequence of Berlin's criticism of the political changes in Poland conducted by LaJ. On the other hand, in the discourse run by that party, Germany, as the strongest country in the EU, has become a negative symbol of the policy leading to Poland's peripheral status in Europe (Morawiecki, 2017). 


\section{INSTITUTIONAL TIES WITH THE WEST}

In the institutional sense, the symbol of the alliance with the West was an idea of getting closer to it, i.e., "ever closer tying up till full membership with Western and Euro-Atlantic organizations" in the 1990s (Pawlak, 1992). The guarantor of security was to be the North Atlantic Alliance, depicted as the most powerful military alliance in the world and a mainstay of freedom and democracy. "Poland in the North Atlantic Alliance is Poland permanently secure, permanently independent" - Prime Minister Jerzy Buzek announced in 1997 (Buzek, 1997). Washington's support for the accession to the Alliance in 1999 and the efforts for the said permanence of security prompted those in charge, regardless of their political colours, to fully submit to the American hegemony in the Alliance to prove "allied credibility". The primary goal was to obtain an insurance policy no longer against the increasingly friendly Germany, but against the threat from the east through Russian imperial policy.

For many years, the Polish integration process was irreversible for the Polish elites and its goal was "safe, democratic and prosperous Europe" (Buzek, 1997). Thus, the elites' discourse framed the unconditional nature of integration with the EU and the necessary clientelism towards the centre - Western Europe, in order to obtain patterns and support for Polish reforms (Bartoszewski, 1995). On the other hand, in contrast to this message, a forward-looking narrative was presented that after a difficult and painful period of transformation, imaginary and real departures from the Western periphery await us, i.e., rapid civilizational and geopolitical advancement. The elites, in response to public fears, developed the idea that the Union would not be divided into better and worse members, and Poland would play a role "appropriate to her position and significance in Central Europe", i.e., the most important one (Cimoszewicz, 2002).

The government of the CP-PPP (Civic Platform/Polish Peasants' Party) in 2007-2015 gradually familiarized the society with the positive effects of the imaginary shift to the West, primarily the EU accession. There was a discussion about how much of the Union and what kind of Poland in it, but the elites created the growing geopolitical and economic position of our country in the Western world. Thus, legitimizing the choice made at the beginning of the Third Independence. Hence the use of the unifying personal pronoun "we" in the discourse, e.g., "We are a part of the West", "a part of the democratic camp" (Kopacz, 2014). 


\section{MOVING AWAY FROM THE WEST}

Alongside the positive consequences, as we have become part of the Western dream, our elites have begun to see its numerous weaknesses as well as disputes, divisions and threats, noticeable especially in the last decade: the economic and the migration crises. As a result, the dark image of the West was constructed among some of the right wing elites. The social process has intensified in which dependence on external patterns is beginning to be seen as evidence of weakness and lack of identity. Then there begins a search for roots in one's own history and national identity, accompanied by the so-called dignity narrative. In this narrative, LaJ began to recreate the imaginary border between "us" - Poland, and "them" - Western Europe. As a result, we began to move away from the West of Europe as a centre (Kuisz, 2016).

This is expressed by a certain discursive opposition, which can be called the controversy between the pro-core or anti-core camps, or Euro-enthusiastic and Euro-sceptic camps, that has continued for years now (Turkowski, 2016). Most of the elites shared the vision of Donald Tusk of 2011 that the game is about how to shift more to the West, "how to be in the centre of Europe, how to be a genuine, key player on the European scene" and not "to be on its periphery". Either "you are at the table, or you are in the menu". Poland had insufficient resources and capabilities, and only close cooperation with the core countries (Germany and France) and deepening the integration allowed her to play a major role in the Union (Tusk, 2011). His successors from LaJ do not strive to be at the table at all costs, as the price for them was the submission to the strongest as an illusion of influence, under the banner of "flowing with the mainstream". It turned out that our entry into the Western structures does not mean quick exit from peripherality nor equal participation in the decision-making processes, as in the polarization discourse our part of Europe is still more "eastern" than "western" in the eyes of many politicians in the West (Matyja, 2018). The visible shortage of the Polish sense of subjectivity and co-responsibility was expressed in the narrative that Western Europe should consider the Polish view of its affairs from the perspective of our interests and identities (Morawiecki, 2017). 


\section{POLAND - THE CENTRE OF CENTRAL-EASTERN EUROPE}

One of the most important parts of our geopolitical representations is the vision of Poland as the centre - the strongest country and the leader of this part of Europe, geopolitically organizing the contracted space between Russia and Germany, whose pressure the region has been struggling with for centuries. To some extent, it was a filiation of the interwar concept of "Isthmus".

Leaving the sense of peripherality and threat behind was to be facilitated by regional cooperation, since 1991 it has been focused within the Visegrad Group (V4). To strengthen the weak position of Poland and other peripheral countries of the region on the path to the Westernisation as a condition for security and development in the geopolitical imagination of our elites, they constructed the vision in the $1990^{\mathrm{s}}$ on the imagined common historical and contemporary fate: "To these nations we are connected not only by historical ties, but also by the common concern for security, heading towards the European Union, awareness of the painful problems of political transformation" (Miller, 2001).

However, the strong desire for unity with the West has weakened this image of Poland as a centre. However, in the first decade of the $21^{\text {st }}$ century, the Visegrad Group did not fall apart, although it became much less active. The multidimensional crisis of the Union, visible in recent years, and destabilization at our eastern borders have created in the eyes of some right-wing elites an opportunity for the Polish geopolitical strategy based on expanding our own autonomy. At the end of 2017, Prime Minister Mateusz Morawiecki suggested the idea: "Central Europe is the source of strength for Poland. And only Poland with its own regional policy in alliance with the USA, open to all Central European countries, can be a member of the Union and a subject in international relations" (Morawiecki, 2017).

Poland should - with American support - remain the leader of our region of Europe, now identified institutionally not only within the V4 group, but also - since 2015 - more widely as the Three Seas Initiative, consisting of 12 countries. In the opinion of the LaJ elites, they are generally associated with similar identities and historical experiences. And now the feeling prevails that Poland is still treated by the "old" EU countries as the worse, "eastern" part of the West, to maintain her peripheral status (Morawiecki, 2017). Characteristically, this discourse presents the region as an imagined cultural unity, the unity of goals and interests, combined with the recognition of the central role of Warsaw. Such 
a vision ignores many differences and disputes, overestimates the central role of Poland, and underestimates the power of influence of the strongest countries in Western Europe, mainly Germany.

\section{IMAGINATIONS OF THE EAST}

Following 1989, Poland returned civilization-wise to the West, which in the $21^{\text {st }}$ century strengthened its geopolitical position towards the East in the eyes of the elites through the system of alliances. It was significant for geopolitical representations. For the goals of Polish eastern policy, framed for many years according to the so-called Jagiellonian idea (although the CP-PPP government declared the use of the more Western Piast Concept) was to move the boundaries of the zone of cultural and political influences of the West to the East, mainly towards Ukraine and Belarus - close to the historical reminiscences from the First and Second PR; and later farther east, e.g., towards Georgia, under the banner of "expanding the areas of security, cooperation and democracy" (Tusk, 2007). It was perceived by Russia as interference in its sphere of influence. This role of the "bulwark" is so deeply rooted in our historical geopolitical representations and national identity, but also that of the "bridge" between the West and the East and in the modern version also the "inspector" who knows what it should be like and therefore quickly determines the difference between the template and reality and administers treatment. In our case, equipped with better western patterns treated as universal and judging others according to them (Czapliński, 2017). Poland, as an example of a successful transformation, was supposed to be an imaginary figure of the West-centre for its eastern neighbours, attracting them with her soft power. Such a paternalistic vision was drawn by, for example, Prime Minister Kazimierz Marcinkiewicz: "We know from our own experience that stability is ensured primarily by democracy and the free market. Therefore, we will continue to support our eastern partners in the work of their reforms, in building the structures of a democratic state of law and civil society" (Marcinkiewicz, 2005).

Among the eastern neighbours the imperial Russia/USSR was identified as a regular "alien" and threat to Poland, in the role of the enemy of Poland and Polishness since the period of partitions, which was somewhat suppressed by the forced friendship during the period of the PPR. Russia in the discourse of the vast majority of the elites was presented as a civilisationally alien and 
geopolitically dangerous world to justify Poland's turn to the West (Skubiszewski, 1992).

Despite various fluctuations or varying assessments, the attitude of the "visitor" and orientalisation towards Russia clearly dominated our elites. As a consequence, the weakening of the Russian threat was possible in their visions by adopting the cultural values of the West by Moscow, treated as better and normal. "It is in the Polish vital interest that behind our eastern border the modern Russian state, not seeking inspiration in the imperial heritage, but building its new identity of a democratic, credible and cooperative state, and especially a good neighbour, should develop" (Meller, 2006). Then Russia shall change her geopolitical identity, i.e., abandon "thinking in terms of power politics, spheres of influence, zero-sum games, [...] which - in the realities and the environment of the European Union - should be history" (Sikorski, 2009).

Still nothing like that occurred, and in recent years, the hostile Cold War rhetoric, which justified the annexation of Crimea and Russia's participation in the war in Ukraine, has re-emerged in the image of Russia. Moscow, instead of democratizing and modernizing herself according to the Western model, continues her imperial policy, destabilizes the political order in Europe, exerts strong, negative influence on the geopolitical situation of Poland, works to weaken the EU and transatlantic cooperation (Czaputowicz, 2018). Therefore, Moscow's cooperation with Warsaw has become hostage not only to the geopolitical relations of the West with the Kremlin, but also to the notions of the necessary cultural rapprochement between Russia and the West, strongly limiting the room for manoeuvre in Poland's eastern policy.

\section{SUMMARY}

The geopolitical imaginations of our political elites placed Poland in Europe, on the periphery of the West, between Germany and Russia, and on the border of the two civilizations. The way out from this "fatalism of geography" was the main goal of the political elites of the Third Polish Republic. Hence the turn towards integration with the world of the West, to which we have belonged culturally for centuries. It required an imaginary shift of Poland from east to west to ensure her security and development. In order to justify such a reconstruction, the elites used the idealized image of the West that is close to us. It facilitated the acceptance of the geopolitical choice made by the society and the related radical 
limitation of Poland's geopolitical and economic autonomy. The vehicles on the way to the West were bandwagoning towards the USA and Germany, which justified clientelism towards them. Poland's position in the West and East of Europe was leveraged by visions of Poland's dominant position in the post-communist region, which intensified during the LaJ government. As for the eastern direction, Poland's goal was to move the imaginary borders of the West to the east, mainly towards our eastern neighbours. This must have led to the negative reaction from Russia, which considers this area as its sphere of influence. Russia was treated, in our representations, as alien, and the change of this state of affairs would be a consequence of the Westernisation of Russia so desired by the Polish elites.

\section{REFERENCES:}

Bartoszewski, W. (1995). Information of the Minister of Foreign Affairs on the Main Directions of Poland's Foreign Policy. Retrieved from: http://www.londyn.msz.gov. pl/resource/bfa922e4-9a33-4fa6-8ae6-9a91b16a5871:JCR.

Bartoszewski, W. (2001). Information of the Minister of Foreign Affairs on the Basic Directions of Poland's Foreign Policy. Retrieved from: http://www.msz.gov.pl/resource/ a3b218eb-5c5c-43ff-b3b2-547a72475f44:JCR.

Bielecki, J.K. (1991). Declaration of the Chairman of the Council of Ministers Jan Krzysztof Bielecki Regarding the Suggested Composition and Program of Government Works. Shorthand Report from the $48^{\text {th }}$ Sitting of the Sejm on January 5, 1991.

Borodziej, W. (ed.) (2006). Polska wobec zjednoczenia Niemiec 1989-1991. Dokumenty dyplomatyczne. Warszawa: Wydawnictwo Scholar.

Buzek, J. (1997). Expose of Prime Minister Jerzy Buzek of November 10, 1997. Retrieved from: https://www.bankier.pl/wiadomosc/Expose-Jerzego-Buzkaz-10-11-1997-7329156.html.

Cimoszewicz, W. (2002). Information of the Minister of Foreign Affairs on the Basic Directions of Poland's Foreign Policy. Retrieved from: http://www.msz.gov.pl/ resource/613f81fb-8145-4595-9012-3a9b13612f16:JCR.

Cimoszewicz, W. (2003). Government Information on Polish Foreign Policy in 2003. Retrieved from: http://www.mfa.gov.pl/resource/14949b50-728d-49e8-8967bb199dda4fa2:JCR.

Cimoszewicz, W. (2004). Government Information on the Tasks of Polish Foreign Policy in 2004. Retrieved from: http://www.msz.gov.pl/resource/3e237cf7-2896-4421-9af87 f3c3228d548:JCR.

Czapliński, P. (2016). Poruszona mapa. Wyobraźnia geograficzno-kulturowa polskiej literatury przełomu XX $i$ XXI wieku. Kraków: Wydawnictwo Literackie. 
Czaputowicz, J. (2018). On the Priorities of Polish Diplomacy in 2018. Retrieved from: https://www.msz.gov.pl/pl/p/msz_pl/aktualnosci/wiadomosci/minister_jacek_ czaputowicz_o_priorytetach_polskiej_dyplomacji_w_2018_roku.

Flint, C. (2008). Wstęp do geopolityki. Warszawa: Wydawnictwo Naukowe PWN.

Fotyga, A. (2007). Information on Polish Foreign Policy in 2007. Retrieved from: http:// www.msz.gov.pl/resource/8bb74522-50c3-44cc-8e87-2431cefba45b:JCR.

Gasztołd, A. (2018). Perspektywa feministyczna w badaniach nad terroryzmem. Retrieved from: http://przeglad.amu.edu.pl/wp-content/uploads/2018/06/pp-2018-2-03.pdf. DOI: $10.14746 / \mathrm{pp} .2018 .23 .2 .3$.

Geremek, B. (1999). Exposé of the Minister of Foreign Affairs in Sejm. Retrieved from: http://stosunki-miedzynarodowe.pl/teksty-zrodlowe/przemowienia/1113-exposministra-spraw-zagranicznych-bronislawa-geremka-w-sejmie-8-kwietnia-1999-r.

Geremek, B. (2000). Information of the Minister of Foreign Affairs on the Basic Directions of Poland's Foreign Policy. Retrieved from: http://www.msz.gov.pl/ resource/5893877e-4197-4f85-bbc3-dbe2df6c3fa9:JCR.

Gregory, D. (1994). Geographical Imaginations. Oxford: Wiley-Blackwell.

Grosse, T.G. (2016). Tragedia państw peryferyjnych, czyli o geopolitycznych dylematach Polski w Unii Europejskiej. In: T. Zarycki (ed.). Polska jako peryferie (pp. 25-50). Warszawa: Wydawnictwo Naukowe Scholar.

Güney, A., \& Gökcan, F. (2010). The 'Greater Middle East' as a 'Modern' Geopolitical Imagination in American Foreign Policy. Geopolitics, 15(1), 22-38. DOI: 10.1080/14650040903420370.

Harvey, D. (2005). The Sociological and Geographical Imaginations. International Journal of Politics, Culture and Society, 18(3-4), 211-255.

Horolets, A. (2006). Obrazy Europy w polskim dyskursie publicznym. Kraków: Universitas.

Kopacz, E. (2014). Exposé of Prime Minister Ewa Kopacz - transcript. Retrieved from: https://www.premier.gov.pl/realizacja-planow/expose-premier-ewy-kopaczstenogram.html.

Kuisz, J. (2016). Koniec mitu Zachodu. Kultura Liberalna, 375. Retrieved from: https:// kulturaliberalna.pl/2016/03/15/mit-zachodu-koniec-jaroslaw-kuisz/.

Kuźniar, R. (2008). Droga do wolności. Polityka zagraniczna III Rzeczypospolitej. Warszawa: Wydawnictwo Naukowe Scholar.

Marcinkiewicz, K. (2005). Exposé of Prime Minister Kazimierz Marcinkiewicz of 2005. Retrieved from: http://www.marcinkiewicz.org/expose.

Matyja, R. (2018). Wyjście awaryjne. O zmianie wyobraźni politycznej. Kraków: Wydawnictwo Karakter.

Meller, S. (2006). Information of the Minister of Foreign Affairs on the Tasks of Polish Foreign Policy in 2006. Retrieved from: http://msz.gov.pl/resource/a9903f58-ddbb4bc0-ba49-ee81c688d690:JCR.

Miller, L. (2001). Presentation by the Chairman of the Council of Ministers Leszek Miller of the Program of Operation of the Council of Ministers Together with the Motion for 
Granting It a Vote of Confidence. Shorthand Report from the $2^{\text {nd }}$ Sitting of the Sejm of the $4^{\text {th }}$ Term of Office of October 25, 2001.

Morawiecki, M. (2017). The Text of Exposé of Prime Minister Mateusz Morawiecki. Retrieved from: https://www.tvn24.pl/wiadomosci-z-kraju,3/tekst-exposemateusza-morawieckiego-co-premier-powiedzial-w-sejmie,798139.html.

Oleksy, J. (1995). Presented by the President of the Council of Ministers Józef Oleksy, the Government's Action Program and the Proposed Composition of the Council of Ministers. Shorthand Report from the $44^{\text {th }}$ Sejm Meeting of the Second Term of March 3, 1995.

Pawlak, W. (1992). Declaration of the Chairman of the Council of Ministers Waldemar Pawlak Regarding the Suggested Composition and Program of Government Works. Shorthand Report from the $19^{\text {th }}$ Sitting of the $1^{\text {st }}$ Term of Sejm on July 1, 1992.

Potulski, J. (2010). Wprowadzenie do geopolityki. Gdańsk: Wydawnictwo Uniwersytetu Gdańskiego.

Rosati, D. (1996). Information of the Minister of Foreign Affairs on the Main Directions of Poland's Foreign Policy. Retrieved from: http://www.msz.gov.pl/resource/dbalc497807d-477b-835c-7e7de94ab0b4:JCR.

Rotfeld, A.D. (2005). Information of the Minister of Foreign Affairs on the Tasks of Polish Foreign Policy in 2005. Retrieved from: http://www.msz.gov.pl/resource/40ad75d816c0-4641-8f72-2bb88391f22a:JCR.

Said, E.W. (2005). Orientalizm. Poznań: Wydawnictwo Zysk i S-ka.

Sikorski, R. (2008). Information of the Minister of Foreign Affairs on the Foreign Policy of the Republic of Poland in 2008. Retrieved from: http://www.msz.gov.pl/ resource/8fc5ad37-d4b5-4938-bdd7-359993e000dc:JCR.

Sikorski, R. (2009). Information of the Minister of Foreign Affairs Regarding the Tasks of Polish Foreign Policy in 2009. Retrieved from: www.mfa.gov.pl/resource/5cff76d31913-4f01-a3c8-480b56c4e9e9:JCR.

Sikorski, R. (2013). Information of the Minister of Foreign Affairs on the Tasks of Polish Foreign Policy in 2013. Retrieved from: http://www.msz.gov.pl/pl/aktualnosci/ wiadomosci/informacja_ministra_spraw_zagranicznych_o_zadaniach_polskiej_polityki_zagranicznej_w_2013_roku.

Skubiszewski, K. (1991). Foreign Policy of the Republic of Poland in 1991. Retrieved from: http://www.msz.gov.pl/resource/1daadebd-a66f-4159-ac9e-2b4d1cd9773d:JCR.

Skubiszewski, K. (1992). Information of the Minister of Foreign Affairs on the Foreign Policy of the Republic of Poland. Retrieved from: http://www.msz.gov.pl/resource/ a2467a85-fabe-4347-9fc6-cedc038e8832:JCR.

Skubiszewski, K. (1993). Government Information on Poland's Foreign Policy. Retrieved from: http://www.msz.gov.pl/resource/d23a9feb-9d2e-45bf-a84e8d68d22fe6c2:JCR.

Szydło, B. (2015). Exposé of Prime Minister Beata Szydło - transcript. Retrieved from: https://www.premier.gov.pl/expose-premier-beaty-szydlo-stenogram.html.

Škrabec, S. (2013). Geografia wyobrażona. Koncepcja Europy Środkowej w XX wieku. Kraków: Międzynarodowe Centrum Kultury. 
Turkowski, A. (2016). Perspektywa centrum - peryferie w analizie dyskursu polskiej polityki wobec Rosji. In: T. Zarycki (ed.). Polska jako peryferie (pp. 148-160). Warszawa: Wydawnictwo Naukowe Scholar.

Tusk, D. (2007). Exposé of Prime Minister Donald Tusk. Retrieved from: http://wyborcza. pl/1,76842,5239927,Expose_premiera_Donalda_Tuska.html.

Tusk, D. (2011). Exposé of Prime Minister Donald Tusk - transcript. Retrieved from: https://premier.gov.pl/realizacja-planow/expose-premiera-donalda-tuska-stenogram.html.

Zięba, R. (2012). Główne kierunki polityki zagranicznej Polski po zimnej wojnie. Warszawa: Oficyna Wydawnicza Łośgraf. 